\title{
Structure, biosynthesis and regulation of lactase-phlorizin hydrolase
}

\author{
By Ove Norén and Hans Sjöström
}

\begin{abstract}
Lactase-phlorizin hydrolase (EC 3.2.1.108; 3.2.1.62) (LPH) is an enterocyte specific enzyme localised to the intestinal brush border. It has a key role in the digestion of lactose. LPH is an ectoenzyme anchored to the microvillar membrane via a C-terminally located hydrophobic stretch and it has an internal homology. LPH is sythesized as a large precursor which during the intracellular transport becomes $\mathrm{N}$ - and $\mathrm{O}$ - glycosylated. During the transport a large propeptide, which serves as a chaperone, is cleaved off before LPH reaches the brush border.

LPH-expression is regulated at the level of LPH-mRNA during both differentiation/tissue specific expression and post-weaning down regulation. A series of regulatory elements together with their transcription factors have been identified. It is suggested that lactase-persistence is caused by a mutation that either destructs a repressive cis-element (or a cis-element binding a destabilising protein) or creates an enhancing cis-element interacting with activating factors which increase after weaning.
\end{abstract}

Keywords: Hypolactasi, lactase, LPH-gene, LPH-promoter, phlorizin hydrolase

\section{Structure and biosynthesis \\ Structure}

Lactase-phlorizin hydrolase (EC 3.2.1.108; 3.2.1.62) (LPH) is an enterocyte specific enzyme carrying out its function in the luminal membrane - the brush border (for a detailed review see (1)). LPH contains two active sites. One is the main player in the intestinal hydrolysis of the $\beta$-galactoside lactose. It hydrolyses also other natural $\beta$-glycosides like cellobiose, cellotriose, cellotetrose and cellulose but with much less efficiency. The other active site hydrolyses $\beta$-glycosides with large hydrophobic alkyl chains like those in galactosyl- and glycosyl- $\beta$-ceramides. The lactase-activity was initially described and characterized by Dahlqvist (2) and Doell and Kretchmer (3) and its presence in mammals has been thoroughly documented (4).

LPH exerts its function in the membrane by an extracellularly located dimer built up of two identical $160 \mathrm{kDa}$ polypeptide chains (Figure 1) (5). The deduced amino acid sequence of LPH infers that the enzyme is anchored to the membrane directly by a hydrophobic $\mathrm{C}$-terminally located stretch rather than via a GPI anchor as the enzyme is not released by phospholipase $\mathrm{C}$ and is not present in the detergent insoluble fraction of the microvillus membrane $(6,7)$. The enzyme that has a short (26 amino acid long) cytoplasmic part can be phosphorylated (8) but the biological importance of this finding is unknown.

The primary translation product of human LPH (pre-pro-LPH) is 1927 amino acid long and shows a fourfold internal homology between the four domains (I-IV) (6). It has a cleavable signal sequence (aa 1-19) and a large pro-peptide (domain I and II) comprising about half of the molecule. Domain III carries the active site responsible for the phlorizin hydrolysis and domain IV harbours the lactase active site $(9,10)$.

Ove Norén, Prof., MD, Hans Sjöström, Prof., MD, Biochemistry Laboratory C, Dept of Medical Biochemistry and Genetics, The Panum Institute, University of Copenhagen, Copenhagen, DK-2200 Denmark.

Correspondence: E-mail: sjostrom@imbg.ku.dk

The article is based on lectures presented at the meeting Lactose intolerance revisited, Febuary 1-2, 2001, Stockholm, Sweden.

\section{Biosynthesis}

Posttranslational modifications: By the use of pulse-chase experiments it was demonstrated that LPH is synthesized as a high mannose N-glycosylated single chain form (pro-LPH) (11-13). LPH dimerizes during ist biosynthesis $(14,15)$. In the case of the human enzyme this occurs during the passage out of ER. In the Golgi apparatus the N-linked high mannose glycosylation is converted into an endo $\mathrm{H}$ resistant complex type glycosylation and here LPH also acquires O-linked glycosylation. This increases the enzymatic activity fourfold (16).

The propeptide of pro-LPH is cleaved off during its transport across the Golgi apparatus. For the human enzyme this occurs after ${ }^{734} \mathrm{Arg}$ leaving a 1192 amino acid long processed form of LPH (mature-like LPH) which is further transported to the brush border membrane. The cleavage is carried out by furin or by a furin-like convertase $(17,18)$. On its way to or in the brush border the mature-like LPH is further processed by a combination of unknown peptidases (e.g. other furins, some aminopeptidases, cathepsins or might be granzyme A) in combination with a final trimming by trypsin (19).

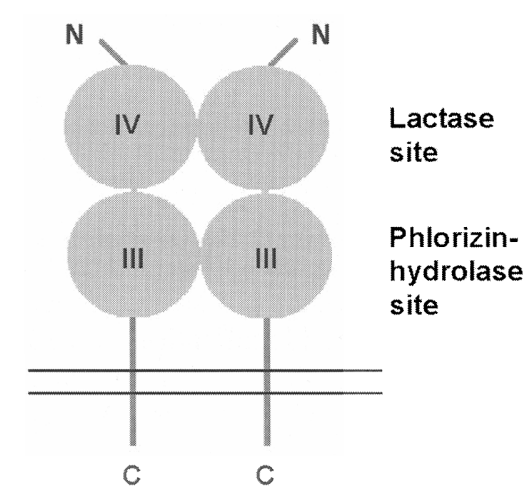

Figure 1. Schematic representation of the mature lactase-phlorizin hydrolase (LPH) complex on the outer side of the apical membrane of the enterocytes. The complex is composed of two complex N-glycosylated and $O$-glycosylated $160 \mathrm{kDa}$ polypeptides. III and IV refer to homologous domains of LPH which harbour the phlorizin hydrolysing and lactose hydrolysing sites respectively. 


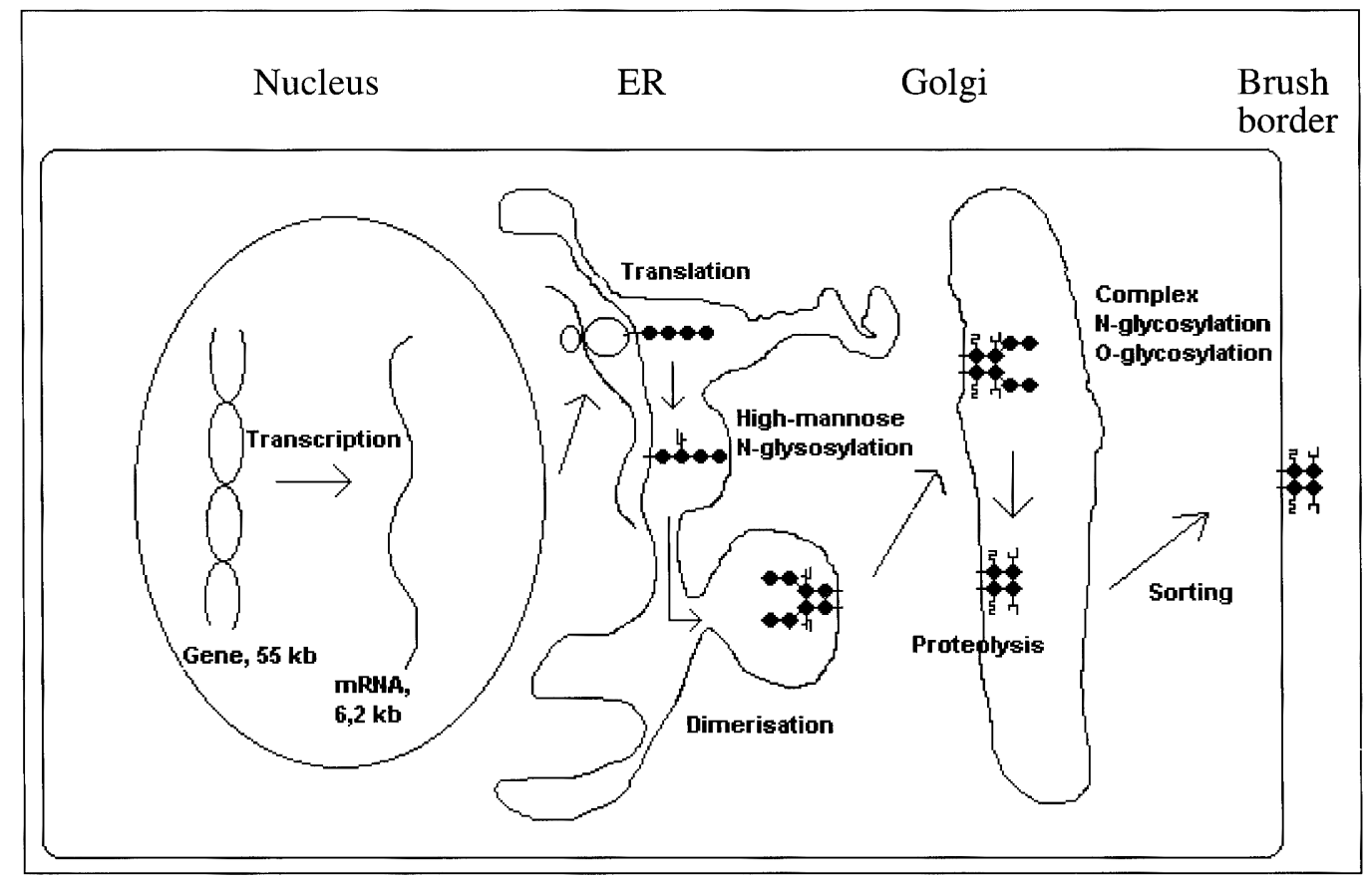

Figure 2. Overview of the biosynthesis of human lactase-phlorizin hydrolase.

The propeptide, which contains domain I and II does not contain structures similar to those carrying out the enzymatic activities on domain III and IV (20) and a search for possible enzymatic activities was without result (21). The cleavage of the pro-LPH has no effect on the enzymatic activity, as the intact proLPH is fully active (22). Separately expressed mature-like LPH devoid of the pro-peptide cannot be transported to the cell surface but is instead degraded intracellularly probably because of incorrect folding. It therefore seems as if the propeptide serves as an intramolecular chaperone securing correct folding of the mature-like LPH necessary for its proper transport to the cell surface (23), Figure 2.

Sorting: Both pro-LPH and the mature-like LPH are predominantly present on the apical membrane of MDCK-cells recombinantly expressing LPH $(24,25)$ indicating that the cleavage process is without influence on the apical sorting of LPH. Studies on deletion mutants followed by expression in MDCK-cells point to the existence of an apical sorting signal in the ectodomain (26). This sorting signal is different from that of sucrase-isomaltase as this enzyme is found in the detergent insoluble fraction but the LPH is not. Furthermore it has elegantly been demonstrated that LPH and SI are transported by different vesicles from the Trans Golgi Network (TGN) to the apical membrane and that they segregate in the TGN (27).

Much focus has been on the sorting of the LPH-molecule. However there are also reports (28-30) reporting on an apical localization of LPH-mRNA. It thus seems as if the biosynthesis of LPH is carried out close to the site of function (the brush border) and that the polarized localisation of the LPH-mRNA is a part of the sorting process. The molecular mechanism for the LPH-mRNA sorting might be either an interaction between a sequence in the LPH-mRNA and an "address molecule" or a similar interaction with the growing LPH-protein.

\section{Regulation of expression}

\section{Regulation of the level of $L P H-m R N A$}

General: The tissue specific expression is mainly controlled by a series of transcription factors that regulate the transcription in a strictly controlled way during the differentiation of an adult stem cell to the mature, functioning cell. In the intestine adult stems cells are located in the crypts. Daughter cells divide and differentiate at the same time as they migrate towards the villi. Transcription factors bind to distinct segments of the DNA in the near upstream region (cis-elements) and thereby regulate transcription of the gene. Binding can also occur to cis-elements at farther distances and both upstream and downstream of the transcribed part of the gene. Once the transcription is activated, its efficiency, which is number of initiations per time, can be regulated by several mechanisms. Variations in the amount of critical transcription factors and their co-factors, other modulating transcription factors and degradation rate of mRNA are examples of such regulatory mechanisms. Degradation, although not described for the LPH-mRNA, is controlled by the binding of stabilising or destabilising proteins to another type of cis-elements rich in adenylate/uridylate (adenylate/uridylaterich elements, AREs) and often located in the 3'-untranslated end (31). All these regulation mechanisms may be responsible for variation of activity along the small intestine and the downregulation after weaning.

The LPH-gene: The human LPH-gene, which comprises $55 \mathrm{~kb}$ contains 17 exons with a length between 79 and $1551 \mathrm{bp} \mathrm{(32).} \mathrm{It}$ is localised on human chromosome $2 \mathrm{q} 21$ and is together with some nearby genes transcribed towards the centromer. Thus 3.3 $\mathrm{kb}$ upstream from the start of transcription of the LPH gene, the next gene MCM6 (minichromosome maintenance deficient 6) is located, followed by the gene encoding aspartyl-tRNA synthetase. The region telomeric to these genes (upstream) has a relative low gene density. Thus in a segment of about $1,2 \mathrm{Mb}$ only one gene (chemokine receptor 4 ) has been characterised. There is no evidence of more LPH-genes in the human genome, although three such genes have been suggested in the rabbit genome (33).

Cis-elements/Transcription factors of importance in differentiation/tissue specific expression: The characterisation of mutants/ polymorphisms in relation to LPH expression levels, in vitro experiments for mapping important gene regions in combination 


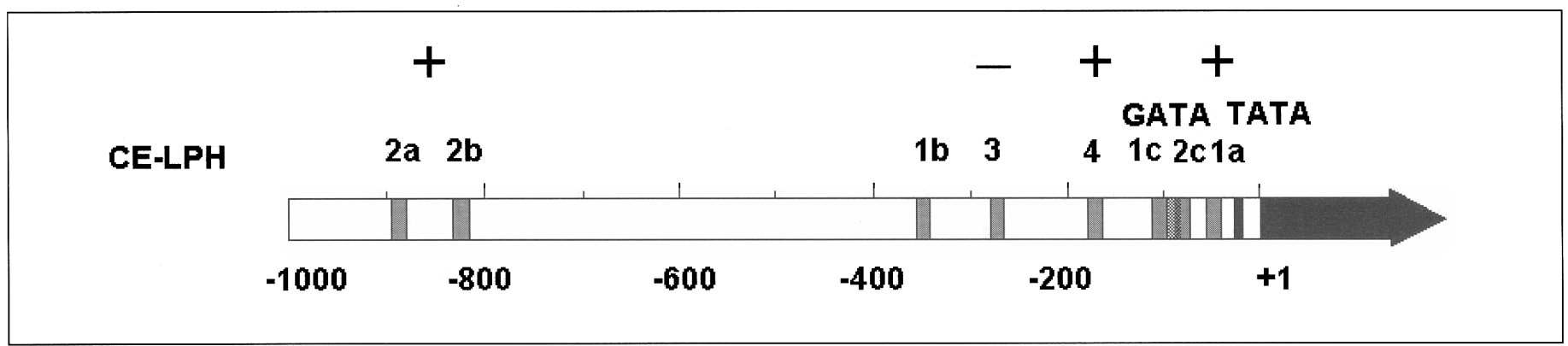

Figure 3. Schematic representation of proposed regulatory cis-elements in the $1 \mathrm{~kb}$ upstream segment of the pig lactase-phlorizin hydrolase (LPH) gene.

with cells in culture and finally studies on transgenic mice have provided information on functional cis-elements and their corresponding transfactors.

Computer searching for known cis-elements in the $1 \mathrm{~kb}$ upstream region of the human LPH-gene suggested that the transcription factors SP-1 (-210), SRF (-250), AP-2 (-410), CTF/ NF1 (-525), CREB (-635) and Oct1/Oct2 (-980) might be of importance for the transcription. The region was furthermore shown to contain two Alu sequences (32). DNAse I footprint experiments showed that a pig intestinal nuclear extract contains transcription factors binding to the region between -40 to -54 of the pig promoter. These factors were not found in a liver nuclear extract (34). This finding was further characterised (35) and using a nuclear extract from Caco- 2 cells, it was demonstrated that the major protein binding to this site, called CE-LPH1a, is a homeodomain protein related to caudal from Drosophila $(36,37)$. This protein is in humans only expressed in intestinal tissue. Two more $\mathrm{Cdx}$ binding sites were later identified in the pig LPH-gene upstream region (CE-LPH1b and 1c) $(38,39)$, and also another transcription factor (HOXC11) with a binding specificity similar to $\mathrm{Cdx}-2$ (39). A detailed deletion analysis of the region between -17 to -894 of the pig LPH promoter revealed both activating and repressing elements (38). Three cis-elements (CE-LPH2a, CE-LPH2b and CE-LPH2c) might be able to bind the transcription factors HNF1 $\alpha$ and $\beta$, which are homeodomain transcription factors being highly expressed in the intestine, liver and kidney. Functional experiments, including transfection experiments in Caco- 2 cells, demonstrated that especially HNF1 $\alpha$, perhaps mostly by binding to CE-LPH2c, is of importance. The deletion experiments further showed that the region between -299 to -227 contains a repressive element. This region contains a binding site for transcription factors belonging to the FREAC family (CE-LPH3, -278 to - 264). Both FREAC 2 and FREAC 3 bind to CE-LPH3 in in vitro experiments and may thus be suggested to have a regulatory function in vivo. Recently, members of the GATA family transcription factors (GATA-4, -5 and -6) have been shown to activate LPH-gene expression in Caco-2 cells (40). There is no doubt an important interaction between some of the suggested factors. Thus interactions between HNF-1 $\alpha$ and $\mathrm{Cdx} 2$ (41) and between HNF-1 $\alpha$ and GATA-5 (42) have been demonstrated.

Experiments with transgenic mice carrying the $1 \mathrm{~kb}$ upstream region of the pig LPH-gene showed that this region contains the cis-elements necessary for correct transcription control in relation to differentiation and tissue-specific expression (43). Similar experiments performed with the rat lactase gene promoter suggested that the region from -2038 to +15 contains regulatory elements with the same functions (44).

Järvelä et al. (45) characterised Finnish families with congenital alactasia, a rare disease, which in opposition to adult-type hypolactasia, leads to complete absence of lactase activity. They suggested that mutation in a region located about $2 \mathrm{Mb}$ upstream of the LPH gene was responsible for the disease. It seems most reasonable to suggest that such an element is responsible for LPH expression in connection with differentiation and tissue specific expression rather than for fine tuning/down-regulation, but further work has to be performed before it can be finally settled.

The current view on transcription factor/cis-elements of importance for the expression of LPH is depicted in Figure 3, which gives the current situation of the pig LPH-gene. Cdx-2 binds to CE-LPH1a(-54 to -40), and CELPH1c(-113 to -90), HNF $1 \alpha$ to CE-LPH2a and 2 c (-894 to -880 and -86 to -71$)$, a FREAC factor or a FREAC related factor to CE-LPH3 ( -278 to -264), GATA factors to an element between -97 and -73 , and finally and an unknown activating factor to CE-LPH4 (in the region -178 to -164$)$.

Cis-elements of importance for the tuning of LPH gene expression: It has been demonstrated in the rat that glucocorticoids and thyroid hormones may affact the lactase activity during the first weeks in life $(46,47)$. These hormones work through receptors that bind to distinct DNA segments, thereby acting as transcription factors. However no glucocorticoid-responsive elements have been detected in the 5'-flanking region of the LPH gene. It may be that it is a more complex response as observed for two other intestinal glycosidases, trehalase and sucrase-isomaltase (48).

Down-regulation of LPH occurs in most mammals and in more than half of the world's human population. It seems very reasonable that the mechanism of this genetic switch is common to all studied species. After a period with conflicting results in the beginning of the $90 \mathrm{~s}$ (see Regulation at the posttranscriptional level, below), it is now generally agreed that the down-regulation is due to decreased amounts of LPH-mRNA. It may, however, be difficult to assess whether this is due to decreased synthesis or increased degradation of LPH-mRNA. Krasinski et al. (49) showed agreement between synthesis rate measured in nuclear run-on assays and steady-state levels of LPH-mRNA in the developing rat intestine, arguing for a transcriptional rate control.

Based on in vitro experiments on the pig promoter, it was suggested that CE-LPH1a might be of importance in the down regulation of lactase after weaning (34). This does however not seem to hold true for rat lactase promoter in a similar experimental approach (50).

More conclusive evidence can be obtained from studies with transgenic animals, containing different regions of promoter region fused to a reporter gene or by the search for mutans/ polymorphisms in humans, that do not down regulate LPH expression after weaning (lactase persistence). By the transgenic mice approach Troelsen et al. (43), reported that the cis-element(s) for down regulation was located within a $1 \mathrm{~kb}$ upstream promoter segment of the pig LPH-gene, whereas Krasinksi et al. 
(44) also by a transgenic approach did not find the corresponding elements in a $2 \mathrm{~kb}$ upstream segment of the rat LPH-gene. It might be that the responsible cis-element in the rat is located further upstream, as the homology between the rat and pig upstream segment is rather low.

Swallow and collaborators have performed an extensive characterisation on human polymorphisms both in the LPH gene exons and introns and also in the region between the LPH and the MCM6 gene (51). The lactase persistence allele was found to be dominant to the non-persistent using symptoms occurring after lactose ingestion for phenotyping. (Half a level of lactase activity is sufficient to digest $50 \mathrm{~g}$ of lactose). However individuals homozygotic for the persistence have higher intestinal LPH expression than the corresponding heterozygotes, allowing them to be differentiated. In an interesting study, characterising LPHmRNA levels in individuals being heterozygous with respect to a distinct polymorphism, it was demonstrated (52) that only the gene with one of the two polymorphisms was expressed in high levels, whereas the other was responsible for $10 \%$ or less of the total LPH-mRNA level. The results distinctly demonstrate that down-regulation is due to a cis-element. However so far no correlation between the many characterised polymorphisms and the LPH persistence/non-persistence have been demonstrated. The different polymorphisms are associated to form some distinct haplotypes, one of which is associated (however not exclusively) to lactase persistence in Europe (53).

\section{Regulation at the posttranscriptional level}

Early studies on LPH regulation using laboratory animals and selected human cohorts made some investigators to suggest a post-translational mechanism for the post-weaning decline and the regulation along the small intestine $(29,54,55)$. However these initial studies were not corroborated in other studies where a more precise experimental desing was used $(49,56,57)$. In these it was reported that the level of LPH-mRNA co-varies with the rate of LPH-biosynthesis, the amount of LPH-activity and LPHprotein. These data suggest that the LPH-level is to a large extent regulated at the transcriptional level as direct studies were carried out on the rate of LPH-mRNA biosynthesis (49).

Is the regulation of the LPH-mRNA levels evenly regulated in all enterocytes or is the LPH-gene silenced in some enterocytes and kept active in others? Is the latter a process in the postweaning downregulation and in other tuning events? The occurrence of a patchy-pattern of LPH seems to be a part of the postweaning downregulation as this has been reported in the postweaning period of rabbit, rats and humans (58-60). No studies aiming at unravelling the molecular mechanisms behind the patchy pattern have been published but it can be hypothesised that either an inherent genetic programme of the enterocytes determines the LPH-gene activity or alternatively external signals from the submucosa are progressively and unevenly changed and is regulating the LPH-gene expression in the neighbouring enterocytes.

Even if it is largely correct to say that the expression of LPH at different levels along the small intestine and at different stages of development is proportional to the LPH-mRNA levels, it is evident that also other factors are modulating the levels of LPHprotein. This is clear as the LPH-mRNA is low or absent on the tips of the enterocyte villi even if the LPH protein is present in significant amounts in the villi $(29,61)$. This indicates that the LPH-protein has a longer half life than LPH-mRNA. Furthermore, a clear discrepancy (high LPH-mRNA vs. low LPH protein/activity) has been observed in the proximal duodenum $(43,60)$ indicating that, e.g. pancreatic proteases reduce the brush border levels of LPH.

\section{Perspectives in relation to adult-type hypolactasia}

A recent publication (62) mentions unpublished data indicating that a cis-element controlling down regulation is located within a $300 \mathrm{~kb}$ region including the LPH gene (Poulter M, Hollox E, Swallow DM, unpublished data). Based on this information it seems very reasonable to suggest that lactose-persistence is caused by a mutation resulting in either destruction of a repressive cis-element (alternatively a cis-element binding a destabilising protein) or the creation of an enhancing ciselement, responding to a transcription factor that increases after weaning.

\section{ABBREVIATIONS}

Cis-elements/Transcription factors see ref (63) for a detailed description

\section{AREs}

Alu sequences

Adenylate/uridylate-rich elements

Caco-2 cells Repetitive sequences recognised

ER

GPI

$\mathrm{LPH}$

LPH-mRNA

MCM6

MDCK-cells

TGN by the restriction enzyme AluI Colorectal adenocarcinoma cell line Endoplasmic reticulum Glycosylphosphatidylinositol Lactase-phlorizin hydrolase Lactase-phlorizin hydrolase messengerRNA Minichromosome maintenance deficient 6 Madin-Darby canine kidney cells Trans Golgi Network

\section{ACKNOWLEDGEMENT}

The cited works from the authors' laboratory were funded by The Danish Health Science Research Council, The Danish Cancer Society, The NovoNordisk Foundation and The Lundbeck Foundation.

\section{REFERENCES}

1. Semenza G, Auricchio S, Mantei N: Small-Intestinal Disaccharidases. In Scriver CR, Beaudet AL, Sly WS, Valle D, eds. The metabolic and molecular basis of inherited diseases. 8th ed. McGraw-Hill, New York, 1999:1623-50.

2. Dahlqvist A: The location of carbohydrases in the digestive tract of the pig. Biochem J 1961;78:282-8.

3. Doell RG, Kretchmer N: Studies of small intestine development.I Distribution and activity of $\beta$-galactosidase. Biochim Biophys Acta 1962; 62:353-62.

4. Semenza G: Intestinal oligo- and disaccharidases. In Randle PJ, Steiner DF, Whelan WJ eds. Carbohydrate Metabolism. Academic Press, London 1981 , 425-79.

5. Skovbjerg H, Sjöström H, Norén O: Purification and characterisation of amphiphilic lactase/phlorizin hydrolase from human small intestine. Eur J Biochem 1981;114:653-61.

6. Mantei N, Villa M, Enzler T, Wacker H, Boll W, James P, Hunziker W, Semenza G: Complete primary structure of human and rabbit lactasephlorizin hydrolase: implications for biosynthesis, membrane anchoring and evolution of the enzyme. EMBO J 1988; 7:2705-13

7. Danielsen EM: Involvement of detergent-insoluble complexes in the intracellular transport of intestinal brush border enzymes. Biochem 1995;34 1596-605.

8. Keller P, Semenza G, Shaltiel S: Disposition of carboxy-terminus tail of rabbit lactase-phlorizin hydrolase elucidated by phosphorylation with protein kinase A in vitro and in tissue culture. FEBS Lett 1995;368:563-7.

9. Arribas JCD, Herrero AG, Martin-Lomas M, Canjada FJ, He S, Withers SG: Differential mechanism-based labelling and unequivocal activity assignment of the two active sites of intestinal lactase/phlorizin hydrolase. Eur J Biochem 2000;267:6996-7005

10. Zecca L, Mesonero JE, Stutz A, Poiree JC, Giudicelli,J, Cursio R, Gloor SM Semenza G: Intestinal lactase-phlorizin hydrolase (LPH): the two catalytic sites; the role of the pancreas in pro-LPH maturation. FEBS Lett 1998;435: 225-8.

11. Danielsen EM, Skovbjerg H, Norén O, Sjöström H: Biosynthesis of intestinal microvillar proteins. Intracellular processing of lactase-phlorizin hydrolase. Biochem Biophys Res Commun 1984;122:82-90.

12. Skovbjerg H, Danielsen EM, Norén O, Sjöström H: Evidence for biosynthesis of lactase-phlorizin hydrolase as a single-chain high highmolecular weight precursor. Biochim Biophys Acta 1984;789:247-51.

13. Naim HY, Sterchi EE, Lentze MJ: Biosynthesis and maturation of lactasephlorizin hydrolase in the human small intestinal cells. Biochem $\mathrm{J} 1987$; 241:427-34.

14. Danielsen EM: Biosynthesis of intestinal microvillar membrane proteins 
Dimerization of aminopeptidase $\mathrm{N}$ and lactase-phlorizin hydrolase. Biochemistry 1990;29:305-8

15. Naim HY, Naim H: Dimerization of lactase-phlorizin hydrolase occurs in the endoplasmic reticulum, involves the putative membrane spanning domain and is required for efficient transport of the enzyme to the cell surface. Eur J Cell Biol 1996;70:198-208

16. Naim HY, Lentze MJ: Impact of O-glycosylation on the function of human intestinal lactase-phlorizin hydrolase.Characterization of glycoforms varying in enzyme activity and localization of O-glycoside addition. J Biol Chem 1992;267:25494-504.

17. Mesonero JE, Gloor SM, Semenza G: Human intestinal prolactase is processed to to an intermediate form by furin-like $\mathrm{PC}(\mathrm{s})$. J Biol Chem 1998; $273: 29430-6$

18. Jacob R, Radebach I, Wüthrich M, Grunberg J, Sterchi EE, Naim HY: Maturation of human intestinal lactase-phlorizin hydrolase: generation of the brush border form of the enzyme involves at least two proteolytic cleavage steps. Eur J Biochem 1996;236:789-95

19. Wütrich M, Grunberg J, Hahn D, Jacob R, Radebach I, Naim HY, Sterchi EE: Proteolytic processing of human lactase-phlorizin hydrolase is a two step event: identification of the cleavage site. Arch Biochem Biophys 1996;336:27-33

20. Wacker H, Keller P, Falchetto R, Legler G, Semenza G: Location of the two catalytic sites in intestinal lactase-phlorizin hydrolase. J Biol Chem 1992; 267:18744-52

21. Naim HY: The pro-region of human intestinal lactase-phlorizin hydrolase is enzymatically inactive towards lactose. Biol Chem Hoppe-Zeyler 1995;376: 255-8.

22. Naim HY, Lacely SW, Sambrook JF, Gething M-J: Expression of a fulllength cDNA coding for human intestinal lactase-phlorizin hydrolase reveals an uncleaved, enzymatically active and transport competent protein. J Biol Chem 1991;266:12313-20.

23. Naim HY, Jacob R, Naim H, Sambrook JF, Gething M-J: The proregion of human intestinal lactase-phlorizin hydrolase. J Biol Chem 1994;269: 26933-43.

24. Jacob R, Brewer C, Fransen JAM, Naim HY: Transport, function and sorting of lactase-phlorizin hydrolase in Madin-Darby canine kidney cells. J Biol Chem 1994;269:2712-21.

25. Jacob R, Zimmer KP, Naim H, Naim HY: The apical sorting of lactasephlorizin hydrolase implicates sorting sequences found in the mature domain. Eur J Cell Biol 1997;72:54-60.

26. Panzer P, Preuss U, Joberty G, Naim HY: Protein domains implicated in intracellular transport and sorting of lactase-phlorizin hydrolase. J Biol Chem 1998;273:13861-9.

27. Jacob R, Naim HY: Apical membrane proteins are transported in distinct vesicular carriers. Curr Biol 2001;11:1444-50.

28. Barth JA, Li W, Krasinski SD, Montgomery RK, Verhave M, Grand RJ: Asymmetrical localization of mRNAs in enterocytes of human jejunum. $\mathrm{J}$ Histochem Cytochem 1998;46:335-43.

29. Duluc I, Jost B, Freund J-N: Multiple levels of control of the stage- and region specific expression of rat intestinal lactase. J Cell Biol 1993;123: 1577-86.

30. Rings EHHM, Büller HA, de Boer PAJ, Grand RJ, Montgomery RK, Lamers WH, Charles R, Moorman AFM: Messenger RNA sorting in enterocytes. Co-localization with encoded proteins. FEBS Lett 1992; 300:183-7.

31. Chen CY, Shyu AB: AU-rich elements: characterisation and importance in mRNA degradation. Trends Biochem Sci 1995;20:465-70.

32. Boll W, Wagner P, Mantei, N: Structure of the chromosomal gene and cDNAs coding for lactase-phlorizin hydrolase in humans with adult-type hypolactasia or persistence of lactase. Am J Hum Genet 1991;48, 889-902.

33. Villa M, Brunschwiler D, Gachter T, Boll W, Semenza G, Mantei N: Region-specific expression of multiple lactase-phlorizin hydrolase genes in intestine of rabbit. FEBS Lett 1993;336:70-4.

34. Troelsen JT, Olsen J, Norén O, Sjöström H: A novel intestinal transfactor (NF-LPH1) interacts with the lactase-phlorizin hydrolase promoter and covaries with the enzymatic activity. J Biol Chem 1992;267:20407-11.

35. Troelsen JT, Olsen J, Mitchelmore C, Hansen GH, Sjöström, H, Norén O: Two intestinal specific nuclear factors binding to the lactase-phlorizin hydrolase and sucrase-isomaltase promoters are functionally related oligomeric molecules. FEBS Lett 1994;342:297-301.

36. Troelsen JT, Mitchelmore C, Spodsberg N, Jensen AM, Norén O, Sjöström $\mathrm{H}$ : Regulation of lactase-phlorizin hydrolase gene expression by the caudal-related homeodomain protein Cdx-2. Biochem J 1997;322:833-8.

37. Fang R, Santiago NA, Olds LC, Sibley, E: The homeodomain protein Cdx2 regulates lactase gene promoter activity during enterocyte differentiation. Gastroenterol 2000;118:115-27.

38. Spodsberg N, Troelsen JT, Carlsson P, Enerbäck S, Sjöström H, Norén O: Transcriptional regulation of pig lactase-phlorizin hydrolase: Involvement of HNF-1 and FREACs. Gastroenterol 1999;116: 842-54.

39. Mitchelmore C, Troelsen JT, Sjöström H, Norén O: The HOXC11 homeodomain protein interacts with the lactase-phlorizin hydrolase promoter and stimulates HFN1 $\alpha$-dependent transcription. J Biol Chem 1998;273:13297306.
40. Fang R, Olds LC, Santiago NA Sibley E: GATA family transcription factors activate lactase gene promoter in intestinal Caco-2 cells. Am J Physiol Gastrointest Liver Physiol 2001;280:G58-G67.

41. Mitchelmore C, Troelsen JT, Spodsberg N, Sjöström H, Norén O: Interaction between the homeodomain proteins $\mathrm{Cdx} 2$ and $\mathrm{HNF} 1 \alpha$ mediates expression of the lactase-phlorizin hydrolase gene. Biochem J 2000;346: 529-35.

42. Krasinski SD, Van Wering HM, Tannemaat, MR, Grand RJ: Differential activation of intestinal gene promoters: functional interactions between GATA-5 and HNF-1 $\alpha$. Am J Physiol Gastrointest Liver Physiol 2001; 281:G69-G84.

43. Troelsen JT, Mehlum A, Olsen J, Spodsberg N, Hansen GH, Prydz H, Norén $\mathrm{O}$, Sjöström $\mathrm{H}: 1 \mathrm{~kb}$ of the lactase-phlorizin hydrolase promoter directs post-weaning decline and small intestinal-specific expression in transgenic mice. FEBS Lett 1994;342:291-6.

44. Krasinski SD, Upchurch BH, Irons SJ, June RM, Mishra K, Grand RJ, Verhave M: Rat lactase-phlorizin hydrolase/human growth hormone transgene is expressed on small intestinal villi in transgenic mice. Gastroenterol 1997; 113:844-55

45. Järvelä, I, Enattah NS, Kokkonen J, Varilo T, Savilahti E, Peltonen L: Assignment of the locus for congenital lactase deficiency to $2 q 21$, in the vicinity of but separate from the lactase-phlorizin hydrolase gene. Am J Hum Genet 1998;63:1078-85.

46. Freund J-N, Foltzer-Jourdainne C, Duluc I, Galluser M, Gosse F, Raul F: Rat lactase activity and mRNA expression in relation to the thyroid and corticoid status. Cell Mol Biol 1991;37:463-6.

47. Yeh KY, Yeh M, Holt PR: Intestinal lactase expression and epithelial cell transit in hormone-treated suckling rats. Am J Physiol 1991;260:G379G84

48. Oesterreicher, TJ, Nanthakumar NN, Winston JH, Henning SJ: Rat trehalase: cDNA cloning and mRNA expression in adult rat tissues and during intestinal ontogeny Am J Physiol Reg Comp Physiol 1998;274:R1220-R7.

49. Krasinski SD, Estrada G, Yeh K-Y, Yeh M, Traber PG, Rings EHHM, Büller HA, Verhave M, Montgomery RK, Grand RJ: Transcriptional regulation of intestinal hydrolase biosynthesis during postnatal development in rats. Am J Physiol Gastrointest Liver Physiol 1994;267:G584-G94.

50. Hecht A, Torbey CF, Korsmo HA, Olsen, WA: Regulation of sucrase and lactase in developing rats: role of nuclear factors that bind to two gene regulatory elements. Gastroenterol 1997;112:803-12.

51. Swallow DM, Hollox EJ: Genetic polymorphism of intestinal lactase activity in adults humans. In Scriver CR, Beaudet AL, Sly WS, Valle D, eds. The metabolic and molecular basis of inherited diseases. 8th ed. McGrawHill, New York, 1999:1651-63.

52. Wang Y, Harvey CB, Pratt WS, Sams VR, Sarner M, Rossi M, Aurrichio S, Swallow DM: The lactase persistence/non-persistence polymorphism is controlled by a cis-acting element. Hum Mol Genet 1995;4:657-62.

53. Harvey CB, Hollox EJ, Poulter M, Wang Y, Rossi M, Auricchio S, Iqbal TH, Cooper BT, Barton R, Sarner M, Korpela R, Swallow DM: Lactase haplotype frequencies in Caucasians: association with the lactase persistence/non-persistence polymorphism. Ann Hum Genet 1998:62 215-23.

54. Sebastio G, Villa M, Sartorio R, Guzzetta V, Poggi V, Auricchio S, Boll W, Mantei N, Semenza G: Control of lactase in human adult type hypolactasia and in weaning rabbits and rats. Am J Hum Genet 1989;45:489-97.

55. Freund J-N, Duluc I, Raul F: Discrepancy between the intestinal lactase enzymatic activity and mRNA accumulation in suckling and adults. FEBS Lett 1989;248:39-42.

56. Sterchi EE, Mills PR, Fransen JAM, Hauri HP, Lenzte MJ, Naim HY, Ginsel $\mathrm{L}$, Bond J: Biogenesis of intestinal lactase-phlorizin hydrolase in adults with lactose intolerance. Evidence for reduced biosynthesis and slowed down maturation in enterocytes. J Clin Invest 1990;86:1329-37.

57. Rossi M, Maiuri L, Fusco MI, Salvati VM, Fuccio A, Auricchio S, Mantei N, Zecca L, Gloor SM, Semenza G: Lactase persistence versus decline in human adults: multifactorial events are involved in down-regulation after weaning. Gastroenterol 1997;112:1506-14.

58. Maiuri L, Rossi M, Raia V, Dáuria S, Swallow D, Quaroni A, Auricchio S: Patchy expression of lactase protein in adult rabbit and rat intestine. Gastroenterol 1992;103:1739-46.

59. Maiuri L, Rossi M, Raia V, Garipoli V, Hughes LA, Swallow D, Norén O, Sjöström H, Auricchio S: Mosaic regulation of lactase in human adult type hypolactasia. Gastroenterol 1994;107:54-60.

60. Rings EHHM, Krasinski SD, van Beers EH, Moorman AFM, Dekker J, Montgomery RK, Grand RJ, Büller HA: Restriction of lactase gene expression along the proximal-to-distal axis of rat small intestine occurs during postnatal development. Gastroenterol 1994;106:1223-32

61. Rings EHHM, de Boer PAJ, Moorman AFM, van Beers EF, Dekker J, Montgomery RK, Grand RJ, Büller HA: Lactase gene expression during early development of rat small intestine. Gastroenterol 1992;103:1154-61.

62. Hollox EJ, Poulter M, Zvarik M, Ferak V, Krause A, Jenkins T, Saha N, Kozlov AI, Swallow DM: Lactase haplotype diversity in the old world. Am J Hum Genetic 2001;68:160-72.

63. Wingender E, Chen X, Hehl R, Karas H, Lieblich I, Matys V, Meinhardt T, Pruss M, Reuter I, Schacherer F:TRANSFAC: an integrated system for gene expression regulation. Nucleic Acids Res 2000;28:316-9. 